\title{
Kisspeptin is released from human prostate cancer cell lines but plasma kisspeptin is not elevated in patients with prostate cancer
}

\author{
ANNETTE E. CURTIS ${ }^{1 *}$, KEVIN G. MURPHY ${ }^{1 *}$, OWAIS B. CHAUDHRI ${ }^{1}$, RADHA RAMACHANDRAN ${ }^{1}$, \\ ANNA-MARY YOUNG ${ }^{2}$, JONATHAN WAXMAN ${ }^{2}$, GURJINDER M.K. NIJHER ${ }^{1}$, GAVIN A. BEWICK ${ }^{1}$, \\ MOHAMMED A. GHATEI ${ }^{1}$, STEPHEN R. BLOOM ${ }^{1}$ and WALJIT S. DHILLO ${ }^{1}$ \\ Departments of ${ }^{1}$ Investigative Medicine, and ${ }^{2}$ Cancer Medicine, Imperial College London, \\ Hammersmith Hospital, Du Cane Road, London W12 0NN, UK
}

Received January 7, 2010; Accepted March 2, 2010

DOI: $10.3892 /$ or_00000818

\begin{abstract}
Kisspeptin, the product of the KiSS-1 gene, inhibits metastasis and stimulates the hypothalamo-pituitarygonadal axis. Kisspeptin is therefore a putative target in the treatment of hormone-sensitive malignancies. Prostatic carcinoma remains a significant cause of mortality despite improvements in therapy. The role of kisspeptin in prostatic carcinoma remains undefined. We therefore aimed to investigate release of kisspeptin by prostatic cancer cell lines; investigate expression of $\mathrm{KiSS}-\mathrm{l}$ in human prostate tissue; investigate whether patients with prostate carcinoma have elevated plasma kisspeptin. 1) Culture medium from prostatic carcinoma cell lines LNCaP, DU145 and PC3 was assayed for kisspeptin immunoreactivity (-IR). Kisspeptin-IR release was detectable from all three cell lines. The effect of hydroxyflutamide, gefitinib and resveratrol on kisspeptin-IR release from these cell lines was also investigated. No effect of the drugs tested on release of kisspeptin-IR was observed. 2) Expression of KiSS-1 in human prostate tissue $(\mathrm{n}=4)$ was investigated using in situ hybridisation. Expression of KiSS-1 was detected in human prostate tissue. 3) Plasma kisspeptin-IR was compared in 92 patients with prostatic carcinoma and 73 male controls. Kisspeptin-IR was not detected in the plasma of either patients with prostate cancer or control patients. We have therefore shown for the first time the release of kisspeptin-IR by prostatic carcinoma cell lines. We have also shown that KiSS-1 is expressed in human prostate tissue, and
\end{abstract}

Correspondence to: Professor Stephen Bloom, Department of Investigative Medicine, Imperial College London, 6th Floor Commonwealth Building, Hammersmith Campus, Du Cane Road, London W12 0NN, UK

E-mail: s.bloom@imperial.ac.uk

${ }^{*}$ Contributed equally

Key words: kisspeptin, metastin, prostate cancer, KiSS-1 that circulating levels of kisspeptin-IR are not elevated in patients with prostatic carcinoma. Further work is required to determine the role of kisspeptin in the prostate.

\section{Introduction}

For more than two decades, prostate carcinoma has remained the most common cancer afflicting men in the USA, and the second highest cause of cancer-related death (1). This despite an overall fall in mortality from prostate carcinoma between 1992 and 2002, attributable to a number of changes in both diagnostic and therapeutic approach (2). The identification of novel points of therapeutic intervention may therefore yield further advances in the treatment of this major source of morbidity and mortality.

Kisspeptin is a 54 amino acid peptide encoded by the gene KiSS-1 (3). In addition to the full length peptide, kisspeptin also exists in vivo as the truncated fragments, kisspeptin-14 and -13 . The minimum sequence required for receptor activation is the C-terminal decapeptide kisspeptin-10 (3). Kisspeptin signals via the G-protein-coupled receptor, GPR54 (3). Kisspeptin is critical to the functioning of the hypothalamo-pituitary-gonadal (HPG) hormonal axis. Mice and humans lacking a functional GPR54 or mice null for KiSS-1 do not mature sexually and have low circulating gonadotrophins and sex hormones (4-10). GPR54, but not $K i S S-1$, is expressed in GnRH neurones in the hypothalamus $(6,11)$. Kisspeptin is thought to modulate sex hormone secretion predominantly via GnRH, but may also exert direct effects on the pituitary and gonads (12-17). Continuous administration of $\mathrm{GnRH}$ has been known for some time to cause downregulation of the HPG axis. The principle mechanism is thought to be downregulation of the GnRH receptor (18). Continuous administration of kisspeptin desensitises the HPG axis to its effects, although in this case, desensitisation is thought to occur at the level of GPR54 (19-21).

Kisspeptin/GPR54 signalling is also thought to be important in tumour biology. Kisspeptin was originally known as metastin because it was implicated in suppression 
of tumour metastasis in a number of human cancers (22-31) and circulating kisspeptin has been proposed as a tumour marker for gestational trophoblastic disease and pancreatic cancer $(32,33)$. However, the levels of kisspeptin in prostatic cancer have not previously been investigated.

Although GPR54 mRNA has been identified in human prostate cDNA by quantitative reverse-transcriptase polymerase chain reaction (RT-PCR), there is disagreement over the expression of KiSS-1. Muir and co-workers (34) failed to detect KiSS-1 expression in cDNA from human prostate, whereas Ohtaki and colleagues (23) did detect KiSS- 1 expression, albeit at comparatively low levels. Furthermore, the expression of KiSS-1 in prostatic cancer has not been investigated. We therefore examined the release of kisspeptin from both androgen sensitive and insensitive human prostate cancer cell lines, and investigated the effects of three common therapeutic agents for prostate cancer on kisspeptin release from these cell lines. We investigated whether KiSS-1 expression could be detected in samples of human prostate tissue using in situ hybridisation (ISH). We also investigated for the first time the circulating levels of kisspeptin in patients with prostate cancer.

\section{Materials and methods}

All chemicals and reagents were obtained from Invitrogen (Paisley, UK) unless otherwise stated.

Cell lines and culture. We used the androgen sensitive prostatic carcinoma cell line LNCaP and the androgen independent cell lines DU145 and PC3. All cell lines were kindly donated by Dr Tahereh Kamalati, Division of Surgery, Oncology, Reproductive Biology and Anaesthetics, Imperial College London, UK.

All cells were cultured in Roswell Park Memorial Institute (RPMI)-1640 medium, supplemented with 10\% fetal bovine serum and $1 \%$ antibiotic (100 IU/ml penicillin and $100 \mu \mathrm{g} / \mathrm{ml}$ streptomycin). Cells were cultured at $37^{\circ} \mathrm{C}, 95 \% \mathrm{O}_{2}, 5 \% \mathrm{CO}_{2}$. The medium was changed every $2-3$ days and cells were passaged on reaching $80-90 \%$ confluence.

Kisspeptin release by human prostate cancer cell lines. LNCaP, DU145 and PC3 cells were cultured as above. Prior to experimental manipulation, cells were plated onto 24-well multidishes pre-coated with Nunc Nunclon surface (Nunc International, Roskilde, Denmark). Cells were allowed to grow to confluence and serum starved in RPMI-1640 medium with $100 \mathrm{IU} / \mathrm{ml}$ penicillin and $100 \mu \mathrm{g} / \mathrm{ml}$ streptomycin (serum-free medium, SFM) for $2 \mathrm{~h}$. In order to investigate the time course of kisspeptin release from human prostate cancer cell lines, $500 \mu \mathrm{l} /$ well fresh SFM was then added $(\mathrm{T}=0)$. Cells were incubated at $37^{\circ} \mathrm{C}$ and medium was collected at $\mathrm{T}=2,4$ or $24 \mathrm{~h}$ ( $\mathrm{n}=4$ wells/group) and stored at $-20^{\circ} \mathrm{C}$ until measurement of kisspeptin immunoreactivity (-IR) using an established radioimmunoassay (RIA) $(32,35-37)$. The RIA antibody cross-reacted $100 \%$ with human kisspeptin-54, kisspeptin-14, and kisspeptin-10 and $<0.01 \%$ with other related RF amide proteins, including prolactin-releasing peptide, RF amiderelated peptide 1 (RFRP1), RFRP2, RFRP3, QRFP43, neuropeptide FF, and neuropeptide AF. The assay detected changes of $2 \mathrm{pmol} / \mathrm{l}$ of plasma kisspeptin-IR with a 95\% confidence limit. The intra- and interassay coefficients of variation were 8.3 and $10.2 \%$, respectively.

Characterisation of kisspeptin-IR released by LNCaP cells. The form of kisspeptin released from LNCaP cells was investigated by reverse phase chromatography as previously described $(32,38)$. Kisspeptin-IR was extracted using SepPak C18 cartridges from 2-ml culture medium taken from LNCaP cells grown to confluence in a flask. The extracted kisspeptin-IR was freeze-dried and resuspended in distilled water with $0.1 \%$ trifluoroacetic acid (TFA). It was then loaded onto a reverse-phase fast protein liquid chromatography (FPLC) column and eluted with a $10-40 \%$ gradient of acetonitrile $(\mathrm{AcN})$ with $0.1 \%$ TFA over $60 \mathrm{~min}$ at a flow rate of $1 \mathrm{ml} / \mathrm{min} /$ fraction. The fractions collected were dried down, reconstituted in assay buffer and kisspeptin-IR measured by RIA.

The effect of hydroxyflutamide, gefitinib and resveratrol on kisspeptin release by human prostate cancer cell lines. The effect of a number of therapeutic agents used in the treatment of prostate cancer on kisspeptin release by LNCaP, DU145 and PC3 cells was also investigated. Cells were plated as in study 2 above and serum starved for $2 \mathrm{~h}$. At $\mathrm{T}=0$, the culture medium was changed and replaced with $500 \mu 1$ SFM or with $500 \mu 1$ SFM containing hydroxyflutamide (an androgen receptor antagonist), gefitinib (a tyrosine kinase inhibitor) or resveratrol (which influences the cell cycle at a number of points). Increasing doses of the therapeutic agents were used $(0.1,1$ or $10 \mu \mathrm{M} ; \mathrm{n}=6$ wells/group). At $\mathrm{T}=2 \mathrm{~h}$, culture medium was removed and stored at $-20^{\circ} \mathrm{C}$ until it was assayed for kisspeptin-IR as above.

In situ hybridisation (ISH) to investigate expression of kisspeptin in prostate tissue. The expression of KiSS-1 in the human prostate has previously been examined using cDNA libraries, with conflicting results $(23,34)$. This is in contrast to the expression of GPR54 mRNA, which was identified in prostate cDNA in both studies $(23,34)$. We therefore examined the expression of KiSS-1 mRNA by direct investigation of human tissue samples.

Samples of anonymised prostate tissue $(n=4)$ were provided by the Tissue Bank at Hammersmith Hospital. Samples were cancer-free prostate sections from patients who had undergone open prostatectomy but were subsequently diagnosed with benign prostatic hypertrophy. Ethical approval was obtained from the Hammersmith and Queen Charlotte's \& Chelsea Hospitals Research Ethics Committee (reference no. 05/ Q0406/154). Samples were prepared by the Department of Histopathology, Hammersmith Hospital. Briefly, samples 3-5-mm thick were prepared by a series of treatments with increasing concentrations of ethanol and xylene before immersion in wax. Wax embedded samples were sliced on a microtome to produce $5-\mu \mathrm{m}$ slices and were mounted on to glass slides for ISH.

ISH was performed as previously described (39). Briefly, sense and antisense, corresponding to nucleotides 212-492 of the human KiSS-1 gene (accession no. NM002256), were radiolabelled with $\left[{ }^{35} \mathrm{~S}\right]$-cytosine triphosphate $(37 \mathrm{MBq})$ 
Table I. Clinical characteristics of prostate cancer patients subclassified by tumour-nodes-metastasis (TNM) classification T value.

\begin{tabular}{|c|c|c|c|c|c|}
\hline & \multicolumn{5}{|c|}{ TNM classification, $\mathrm{T}$ value (primary tumour) } \\
\hline & $\mathrm{T} 1$ & $\mathrm{~T} 2$ & $\mathrm{~T} 3$ & $\mathrm{~T} 4$ & $\mathrm{Tx}$ \\
\hline $\mathrm{n}$ & 11 & 31 & 28 & 11 & 11 \\
\hline Mean age (years) \pm SEM & $68.2 \pm 3.0$ & $71.5 \pm 1.1$ & $72.4 \pm 1.5$ & $77.0 \pm 2.4$ & $76.7 \pm 2.9$ \\
\hline Metastatic disease, n (\%) & $0(0)^{\mathrm{c}}$ & $1(3.2)^{\mathrm{c}}$ & $4(14.3)^{\mathrm{c}}$ & $5(45.5)^{\mathrm{c}}$ & $11(100)^{\mathrm{c}}$ \\
\hline Antiandrogen therapy, n (\%) & $1(9.1)^{\mathrm{b}}$ & $2(6.5)^{b}$ & $5(17.9)^{\mathrm{b}}$ & $5(45.5)^{b}$ & $4(36.4)^{\mathrm{b}}$ \\
\hline GnRH agonist therapy, $\mathrm{n}(\%)$ & $3(27.3)$ & $5(16.1)$ & $7(25.0)$ & $5(45.5)$ & $5(45.5)$ \\
\hline Mean PSA $(\mathrm{ng} / \mathrm{ml}) \pm \mathrm{SEM}$ & $2.31 \pm 1.2$ & $14.03 \pm 4.22$ & $28.18 \pm 9.00$ & $14.82 \pm 8.29$ & $419.3 \pm 186.3^{a}$ \\
\hline
\end{tabular}

The number of patients from each group undergoing therapy with antiandrogenic drugs or a GnRH agonist at the time of blood sampling is also shown. n, number; SEM, standard error of the mean; GnRH, gonadotrophin releasing hormone; PSA, prostate specific antigen. Mean age and PSA analysed by One-way ANOVA with Bonferroni post-test. Presence of metastases, use of antiandrogen therapy and use of GnRH therapy analysed by Chi-squared test. ${ }^{\mathrm{a}} \mathrm{P}<0.001 \mathrm{Tx}$ samples vs. $\mathrm{T} 1, \mathrm{~T} 1, \mathrm{~T} 3$ and $\mathrm{T} 4$ samples. ${ }^{\mathrm{b}} \mathrm{P}<0.05$ by Chi-squared test for equal distribution of antiandrogen therapy across different $\mathrm{T}$ values. ${ }^{\mathrm{c}} \mathrm{P}<0.001$ by Chi-squared test for equal distribution of presence of metastases across different $\mathrm{T}$ values.

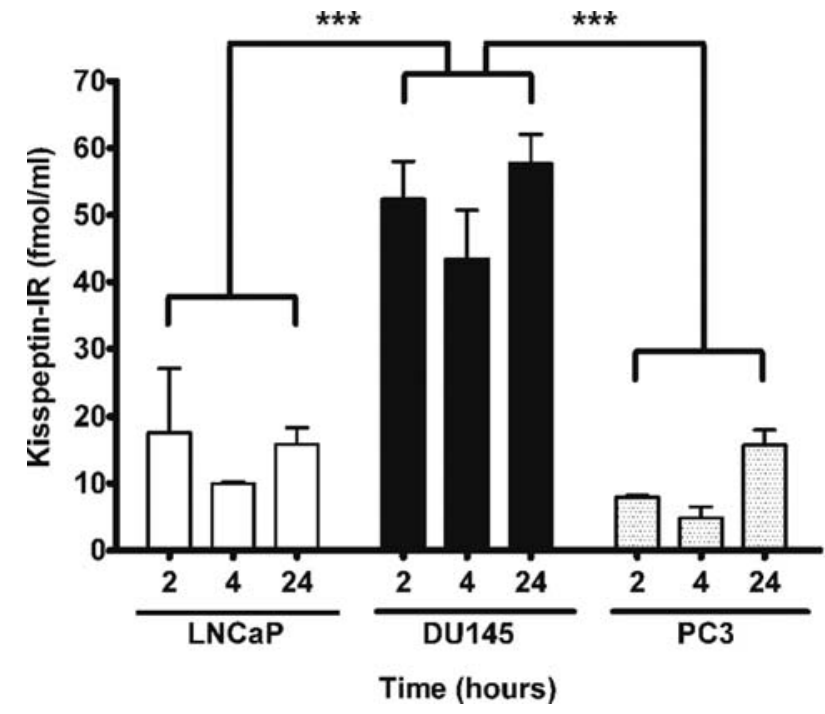

Figure 1. Kisspeptin-IR release from human prostate cancer cell lines LNCaP, DU145 and PC3. Cells were investigated after a 2-h serum starvation, following which fresh serum-free medium (SFM) was added and then removed 2, 4 or 24 h later. No kisspeptin-IR was detected in SFM (data not shown). ${ }^{* * *} \mathrm{p}<0.001$ (Two-way ANOVA with Bonferroni post-test).

(Amersham Biosciences, Buckinghamshire, UK). Hybridisation buffer was supplemented with probe at a rate of $1 \times 10^{5} \mathrm{~Bq} / \mu 1$ and incubated overnight at $60^{\circ} \mathrm{C}$. Slides were then RNAse-A treated, washed, air-dried and exposed to autoradiographic film (Bio-Max Film MR, Kodak, Hemel Hempstead, UK). After exposure, the film was developed and KiSS-1 expression determined by observation of specific hybridisation.

Investigation of plasma kisspeptin-IR in patients with prostate cancer. Blood samples were collected from 92 patients with prostate cancer. Table I shows the clinical characteristics of these patients subclassified by the $\mathrm{T}$ value assigned by the tumour-nodes-metastasis (TNM) classification (40). Plasma was also obtained from 73 male controls who attended the oncology clinic with a diagnosis of malignancy other than prostatic carcinoma (mean age \pm standard error of the mean, SEM: 70.4 \pm 3.4 years). Levels of kisspeptin-IR was measured by RIA in the plasma of patients and controls. Volunteers gave written informed consent and the study was conducted in accordance with the Declaration of Helsinki. Ethical approval was obtained from the Hammersmith and Queen Charlotte's \& Chelsea Hospitals Research Ethics Committee (reference no. 04/Q0406/80).

\section{Results}

Kisspeptin release by human prostate cancer cell lines. Kisspeptin-IR was detected in the culture medium of all three cell lines investigated (Fig. 1). There was no statistically significant effect of time on the release of kisspeptin-IR within any of the cell lines, up to $24 \mathrm{~h}$. DU145 cells released significantly more kisspeptin than either LNCaP or PC3 cells [mean kisspeptin-IR $(\mathrm{pmol} / \mathrm{l}) \pm$ standard error of the mean (SEM) at $\mathrm{T}=2 \mathrm{~h}$ : LNCaP cells 17.6 \pm 19.5 , DU145 cells $52.4 \pm 5.6(\mathrm{p}<0.001$ vs. LNCaP and PC3 cells), PC3 cells $7.9 \pm 0.3$; at $\mathrm{T}=4 \mathrm{~h}: \mathrm{LNCaP}$ cells $9.9 \pm 0.2$, DU145 cells $43.5 \pm 7.2$ ( $\mathrm{p}<0.001$ vs. LNCaP and PC3 cells), PC3 cells

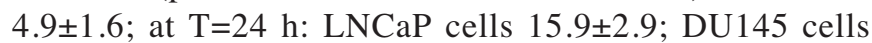
$57.7 \pm 4.4(\mathrm{p}<0.001$ vs. LNCaP and PC3 cells); PC3 cells $15.8 \pm 2.2]$. Statistics by Two-way analysis of variance (ANOVA) with Bonferroni post-hoc test.

Characterisation of kisspeptin-IR released by LNCaP cells. Reverse phase FPLC was used to characterise further the kisspeptin-IR detected in the culture medium of $\mathrm{LNCaP}$ cells. Recovery was $>60 \%$ for all columns. A single immunoreactive peak was detected in each sample of culture medium 


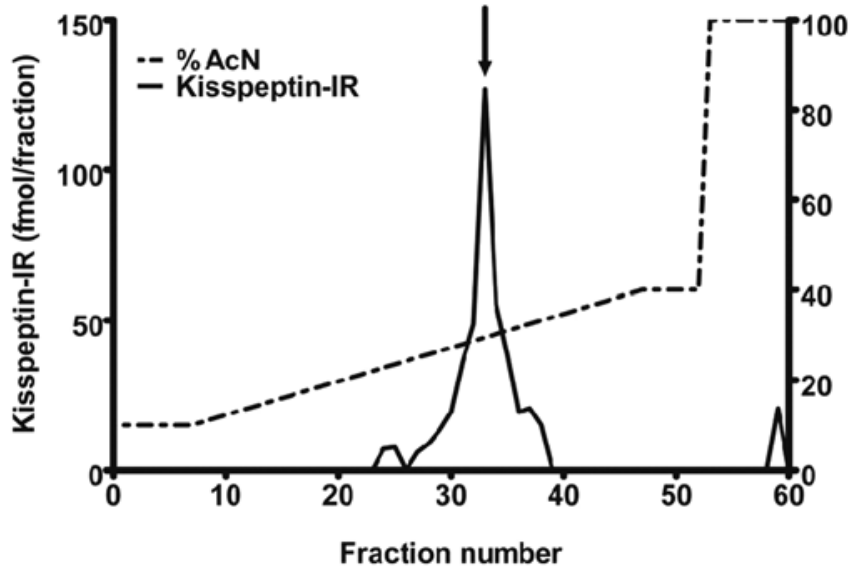

Figure 2. Representative elution profile of kisspeptin-IR extracted from $2 \mathrm{ml}$ of LNCaP medium by Sep-Pak cartridge and fractionated by reverse-phase FPLC. Dotted line indicates \% acetonitrile $(\mathrm{AcN})$; arrow indicates elution position of synthetic human kisspeptin-54.

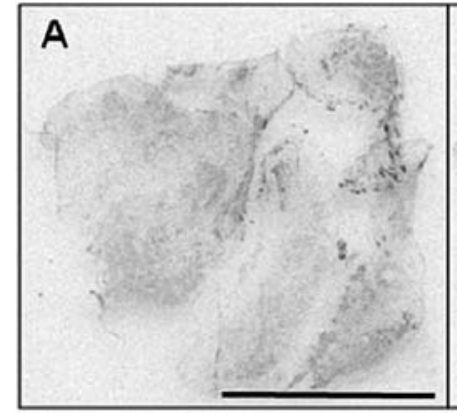

Antisense

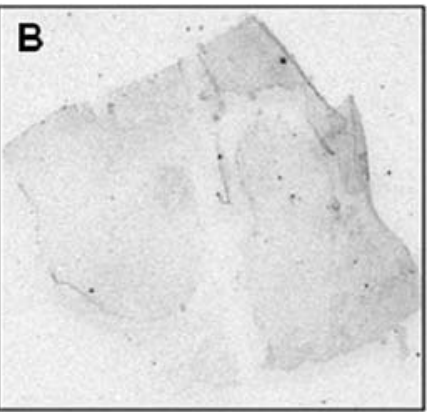

Sense
Figure 3. Representative autoradiograph of in situ hybridisation indicating KiSS-1 mRNA expression in human prostate tissue using an antisense riboprobe (A) and a sense (control) riboprobe (B). Dark staining indicates hybridisation. Scale bar indicates $5 \mathrm{~mm}$.

tested, corresponding to the elution point of synthetic human kisspeptin-54 (Fig. 2).

The effect of hydroxyflutamide, gefitinib and resveratrol on kisspeptin release by human prostate cancer cell lines. The effects of the drugs hydroxyflutamide, gefitinib and resveratrol on release of kisspeptin-IR by LNCaP, DU145 and PC3 cells were investigated. The drugs were each tested at a range of doses: $0,0.03,0.1,0.3,1$ and $10 \mu \mathrm{M}$. No significant effect on kisspeptin-IR at any of the doses tested was observed, compared with basal levels of kisspeptin-IR in both the androgen sensitive and insensitive cell lines (data not shown).

ISH to investigate expression of kisspeptin in prostate tissue. Kisspeptin expression in prostate tissue was investigated using ISH. The KiSS- 1 antisense riboprobe resulted in significantly greater staining than the sense (control) probe, throughout prostate tissue in all samples examined $(n=4)$. This indicates expression of KiSS-1 mRNA in human prostate tissue (Fig. 3).
Investigation of plasma kisspeptin-IR in patients with prostate cancer. Plasma kisspeptin-IR was not detectably raised in patients with prostate cancer, independent of the TNM classification and treatment status of the patient (mean kisspeptin-IR $<2 \mathrm{pmol} / \mathrm{l}$; mean kisspeptin-IR in plasma of healthy male controls $<2 \mathrm{pmol} / \mathrm{l})$. There was no correlation with serum PSA level and plasma kisspeptin-IR.

\section{Discussion}

Kisspeptin was first characterised in relation to its antimetastatic properties. Loss of kisspeptin expression has been associated with increased metastasis and cancer progression in a number of human cancers, including melanoma, phaeochromocytoma, oesophageal squamous cell carcinoma and cancers of the bladder, breast, stomach and pancreas (22-31). In addition, circulating levels of kisspeptin-IR have been proposed as a tumour marker in gestational trophoblastic disease and pancreatic cancer $(32,33)$. However, its role in prostate cancer has not been determined.

Furthermore, kisspeptin is critical in regulation of the hypothalamo-pituitary-gonadal (HPG) axis $(8-12,16,35,36,41,42)$. Current treatment strategies for prostatic carcinoma include modulation of the HPG axis with antiandrogenic drugs and downregulation of HPG axis function with continuous administration of $\mathrm{GnRH}$ analogues. Kisspeptin is thought to act upstream of GnRH in its effects on the HPG axis (12-14,16,41-44) and frequent or continuous administration of kisspeptin has also been shown to cause a reduction in HPG axis function in rodents and primates (19-21). Thus, establishing a role for kisspeptin in prostate carcinoma may indicate possible novel therapeutic approaches.

Kisspeptin-IR was detected in culture medium from all three cell lines investigated. It has previously been noted that prostate cancer cells produce GnRH-like peptides and these have been implicated in the autocrine regulation of prostate cancer (45). In a similar fashion, it is possible that kisspeptin may also act as an autocrine agent, regulating tumour growth. The identification of alternative, novel regulators of tumour growth may suggest possible points of therapeutic intervention, particularly in those patients undergoing therapy with GnRH agonists who escape control. However, all three cell lines used originate from patients with metastatic disease. The detection of kisspeptin-IR released by these cells might therefore seem to conflict with published data, which has associated metastatic potential and disease progression with loss of KiSS-1 expression in other cancers (22-31). Further work, such as studies of the effect of kisspeptin on the response of prostate cancer to growth factors, would further illuminate the implications of local production of kisspeptin for cancer growth and spread.

In order to better understand the significance of the release of kisspeptin-IR by the three cell lines investigated, we investigated the effect of a number of drugs on release of kisspeptin-IR by LNCaP, DU145 and PC3 cells. The drugs chosen act via different mechanisms. Hydroxyflutamide is an androgen receptor antagonist used in the treatment of prostate cancer (46); gefitinib is an inhibitor of the tyrosine kinase domain of the epidermal growth factor receptor (47); and resveratrol is a phytoalexin, acting at a number of points 
in the cell cycle, and has been associated with reduction of prostate cancer progression in mice (48). The lack of an effect of these drugs on kisspeptin-IR release in all three cell lines investigated suggests that kisspeptin does not play a role in mediating the clinical effects of these drugs. This lack of effect was independent of the androgen sensitivity status of the cell line tested.

In order to investigate whether the release of kisspeptinIR by these cell lines was confined to carcinomatous cells, or whether there might be a role for kisspeptin in normal prostate physiology, we also performed ISH for KiSS-I mRNA in tissue samples taken from patients suffering from benign prostatic hypertrophy. KiSS-1 mRNA was present in human prostate tissue. Previous studies of human cDNA libraries have either failed to show expression of KiSS-1 mRNA in prostatic tissue (34), or have shown expression at comparatively low levels (23). In contrast, there is greater agreement on the presence of GPR54 mRNA in human prostate cDNA $(23,34)$. Although not quantitative, our data, derived directly from tissue, support the expression of KiSS-1 mRNA in the human prostate. Kisspeptin may thus play a novel autocrine or paracrine role in normal prostate physiology. The nature of this role requires further investigation.

Our data show that kisspeptin-IR is released by a number of prostatic carcinoma cell lines and that KiSS- 1 mRNA is present in prostate tissue. We therefore went on to investigate whether kisspeptin-IR was measurable in the circulation of patients with prostate carcinoma and whether this correlated with disease stage, the presence of known metastases and treatment modality. Our data suggest that circulating kisspeptin does not play a role in the pathology of prostate cancer. Further work is required to determine whether kisspeptin plays a paracrine or an autocrine role for kisspeptin in prostate cancer.

\section{Acknowldgements}

WSD is supported by a by an National Institute for Health Research (NIHR) Clinician Scientist Award [DHCS/03/ G121/48] and a Wellcome Trust Value in People Award [PS1021.DDMH]. K.G.M. is supported by a Biotechnology and Biological Sciences Research Council New Investigator award [BB/C515398/1]. G.M.N.K. is a Wellcome Trust Clinical Research Fellow [087180/Z/08/Z]. This research was funded by programme grants from the Medical Research Council [G7811974] and Wellcome Trust [072643/Z/03/Z] and by a European Union FP6 Integrated Project Grant [LSHM-CT2003-503041]. We are also grateful for support from the NIHR Biomedical Research Centre funding scheme. The authors are most grateful to all the volunteers who participated in this study. They would also like to thank Dr Tahereh Kamalati, Division of Surgery, Oncology, Reproductive Biology and Anaesthetics, Imperial College London for providing the cell lines used.

\section{References}

1. Jemal A, Siegel R, Ward E, Hao Y, Xu J, Murray T and Thun MJ: Cancer statistics, 2008. CA Cancer J Clin 58: 71-96, 2008.
2. Edwards BK, Brown ML, Wingo PA, Howe HL, Ward E, Ries LA, Schrag D, Jamison PM, Jemal A, Wu XC, Friedman C, Harlan L, Warren J, Anderson RN and Pickle LW: Annual report to the nation on the status of cancer, 1975-2002, featuring population-based trends in cancer treatment. J Natl Cancer Inst 97: 1407-1427, 2005

3. Kotani M, Detheux M, Vandenbogaerde A, Communi D, Vanderwinden JM, Le PE, Brezillon S, Tyldesley R, SuarezHuerta N, Vandeput F, Blanpain C, Schiffmann SN, Vassart G and Parmentier M: The metastasis suppressor gene KiSS-1 encodes kisspeptins, the natural ligands of the orphan $\mathrm{G}$ proteincoupled receptor GPR54. J Biol Chem 276: 34631-34636, 2001.

4. de Roux N, Genin E, Carel JC, Matsuda F, Chaussain JL and Milgrom E: Hypogonadotropic hypogonadism due to loss of function of the KiSS1-derived peptide receptor GPR54. Proc Natl Acad Sci USA 100: 10972-10976, 2003.

5. Funes S, Hedrick JA, Vassileva G, Markowitz L, Abbondanzo S, Golovko A, Yang S, Monsma FJ and Gustafson EL: The KiSS-1 receptor GPR54 is essential for the development of the murine reproductive system. Biochem Biophys Res Commun 312: $1357-1363,2003$.

6. Kauffman AS, Gottsch ML, Roa J, Byquist AC, Crown A, Clifton DK, Hoffman GE, Steiner RA and Tena-Sempere M: Sexual differentiation of Kiss 1 gene expression in the brain of the rat. Endocrinology 148: 1774-1783, 2007.

7. Lapatto R, Pallais JC, Zhang D, Chan YM, Mahan A, Cerrato F, Le WW, Hoffman GE and Seminara SB: Kiss1-/- mice exhibit more variable hypogonadism than Gpr54-/- mice. Endocrinology 148: 4927-4936, 2007

8. Seminara SB, Messager S, Chatzidaki EE, Thresher RR, Acierno JS Jr, Shagoury JK, Bo-Abbas Y, Kuohung W, Schwinof KM, Hendrick AG, Zahn D, Dixon J, Kaiser UB, Slaugenhaupt SA, Gusella JF, O'Rahilly S, Carlton MB, Crowley WF Jr, Aparicio SA and Colledge WH: The GPR54 gene as a regulator of puberty. N Engl J Med 349: 1614-1627, 2003.

9. Semple RK, Achermann JC, Ellery J, Farooqi IS, Karet FE, Stanhope RG, O'Rahilly S and Aparicio SA: Two novel missense mutations in g protein-coupled receptor 54 in a patient with hypogonadotropic hypogonadism. J Clin Endocrinol Metab 90: 1849-1855, 2005.

10. d'Anglemont de Tassigny X, Fagg LA, Dixon JP, Day K, Leitch HG, Hendrick AG, Zahn D, Franceschini I, Caraty A, Carlton MB, Aparicio SA and Colledge WH: Hypogonadotropic hypogonadism in mice lacking a functional Kiss1 gene. Proc Natl Acad Sci USA 104: 10714-10719, 2007.

11. Gottsch ML, Clifton DK and Steiner RA: Kisspepeptin-GPR54 signaling in the neuroendocrine reproductive axis. Mol Cell Endocrinol 254-255: 91-96, 2006.

12. Han SK, Gottsch ML, Lee KJ, Popa SM, Smith JT, Jakawich SK, Clifton DK, Steiner RA and Herbison AE: Activation of gonadotropin-releasing hormone neurons by kisspeptin as a neuroendocrine switch for the onset of puberty. J Neurosci 25 : 11349-11356, 2005.

13. Irwig MS, Fraley GS, Smith JT, Acohido BV, Popa SM, Cunningham MJ, Gottsch ML, Clifton DK and Steiner RA: Kisspeptin activation of gonadotropin releasing hormone neurons and regulation of KiSS-1 mRNA in the male rat. Neuroendocrinology 80: 264-272, 2004.

14. Matsui $\mathrm{H}$, Takatsu $\mathrm{Y}$, Kumano $\mathrm{S}$, Matsumoto $\mathrm{H}$ and Ohtaki T: Peripheral administration of metastin induces marked gonadotropin release and ovulation in the rat. Biochem Biophys Res Commun 320: 383-388, 2004

15. Messager S, Chatzidaki EE, Ma D, Hendrick AG, Zahn D, Dixon J, Thresher RR, Malinge I, Lomet D, Carlton MB, Colledge WH, Caraty A and Aparicio SA: Kisspeptin directly stimulates gonadotropin-releasing hormone release via $\mathrm{G}$ proteincoupled receptor 54. Proc Natl Acad Sci USA 102: 1761-1766, 2005.

16. Thompson EL, Patterson M, Murphy KG, Smith KL, Dhillo WS, Todd JF, Ghatei MA and Bloom SR: Central and peripheral administration of kisspeptin-10 stimulates the hypothalamicpituitary-gonadal axis. J Neuroendocrinol 16: 850-858, 2004.

17. Tovar S, Vazquez MJ, Navarro VM, Fernandez-Fernandez R, Castellano JM, Vigo E, Roa J, Casanueva FF, Aguilar E, Pinilla L, Dieguez C and Tena-Sempere M: Effects of single or repeated intravenous administration of kisspeptin upon dynamic LH secretion in conscious male rats. Endocrinology 147: 2696-2704, 2006. 
18. Tammela T: Endocrine treatment of prostate cancer. J Steroid Biochem Mol Biol 92: 287-295, 2004.

19. Seminara SB, Dipietro MJ, Ramaswamy S, Crowley WF Jr and Plant TM: Continuous human metastin 45-54 infusion desensitizes $\mathrm{G}$ protein-coupled receptor 54-induced gonadotropinreleasing hormone release monitored indirectly in the juvenile male Rhesus monkey (Macaca mulatta): a finding with therapeutic implications. Endocrinology 147: 2122-2126, 2006.

20. Thompson EL, Murphy KG, Patterson M, Bewick GA, Stamp GW, Curtis AE, Cooke JH, Jethwa PH, Todd JF, Ghatei MA and Bloom SR: Chronic subcutaneous administration of kisspeptin-54 causes testicular degeneration in adult male rats. Am J Physiol Endocrinol Metab 291: E1074-E1082, 2006.

21. Ramaswamy S, Seminara SB, Pohl CR, Dipietro MJ, Crowley WF Jr and Plant TM: Effect of continuous intravenous administration of human metastin 45-54 on the neuroendocrine activity of the hypothalamic-pituitary-testicular axis in the adult male rhesus monkey (Macaca mulatta). Endocrinology 148: 3364-3370, 2007.

22. Lee JH and Welch DR: Suppression of metastasis in human breast carcinoma MDA-MB-435 cells after transfection with the metastasis suppressor gene, KiSS-1. Cancer Res 57: 2384-2387, 1997.

23. Ohtaki T, Shintani Y, Honda S, Matsumoto H, Hori A, Kanehashi K, Terao Y, Kumano S, Takatsu Y, Masuda Y, Ishibashi Y, Watanabe T, Asada M, Yamada T, Suenaga M, Kitada C, Usuki S, Kurokawa T, Onda H, Nishimura O and Fujino M: Metastasis suppressor gene KiSS-1 encodes peptide ligand of a G-protein-coupled receptor. Nature 411: 613-617, 2001 .

24. Lee JH, Miele ME, Hicks DJ, Phillips KK, Trent JM Weissman BE and Welch DR: KiSS-1, a novel human malignant melanoma metastasis-suppressor gene. J Natl Cancer Inst 88: 1731-1737, 1996.

25. Shirasaki F, Takata M, Hatta N and Takehara K: Loss of expression of the metastasis suppressor gene KiSS1 during melanoma progression and its association with $\mathrm{LOH}$ of chromosome 6q16.3-q23. Cancer Res 61: 7422-7425, 2001.

26. Ohta S, Lai EW, Pang AL, Brouwers FM, Chan WY, Eisenhofer G, de Krijger R, Ksinantova L, Breza J, Blazicek P, Kvetnansky R, Wesley RA and Pacak K: Downregulation of metastasis suppressor genes in malignant pheochromocytoma. Int J Cancer 114: 139-143, 2005

27. Ikeguchi M, Yamaguchi K and Kaibara N: Clinical significance of the loss of KiSS-1 and orphan G-protein-coupled receptor (hOT7T175) gene expression in esophageal squamous cell carcinoma. Clin Cancer Res 10: 1379-1383, 2004

28. Sanchez-Carbayo M, Capodieci P and Cordon-Cardo C: Tumor suppressor role of KiSS-1 in bladder cancer: loss of KiSS-1 expression is associated with bladder cancer progression and clinical outcome. Am J Pathol 162: 609-617, 2003.

29. Stark AM, Tongers K, Maass N, Mehdorn HM and Held-Feindt J: Reduced metastasis-suppressor gene mRNA-expression in breast cancer brain metastases. J Cancer Res Clin Oncol 131: 191-198, 2005

30. Dhar DK, Naora H, Kubota H, Maruyama R, Yoshimura H, Tonomoto Y, Tachibana M, Ono T, Otani H and Nagasue N: Downregulation of KiSS-1 expression is responsible for tumor invasion and worse prognosis in gastric carcinoma. Int $\mathbf{J}$ Cancer 111: 868-872, 2004.

31. Masui T, Doi R, Mori T, Toyoda E, Koizumi M, Kami K, Ito D, Peiper SC, Broach JR, Oishi S, Niida A, Fujii N and Imamura M: Metastin and its variant forms suppress migration of pancreatic cancer cells. Biochem Biophys Res Commun 315: 85-92, 2004.

32. Dhillo WS, Savage P, Murphy KG, Chaudhri OB, Patterson M Nijher GM, Foggo VM, Dancey GS, Mitchell H, Seckl MJ, Ghatei MA and Bloom SR: Plasma kisspeptin is raised in patients with gestational trophoblastic neoplasia and falls during treatment. Am J Physiol Endocrinol Metab 291: E878-E884, 2006.

33. Katagiri F, Nagai K, Kida A, Tomita K, Oishi S, Takeyama M, Doi R and Fujii N: Clinical significance of plasma metastin level in pancreatic cancer patients. Oncol Rep 21: 815-819, 2009.
34. Muir AI, Chamberlain L, Elshourbagy NA, Michalovich D, Moore DJ, Calamari A, Szekeres PG, Sarau HM, Chambers JK, Murdock P, Steplewski K, Shabon U, Miller JE, Middleton SE, Darker JG, Larminie CG, Wilson S, Bergsma DJ, Emson P, Faull R, Philpott KL and Harrison DC: AXOR12, a novel human $\mathrm{G}$ protein-coupled receptor, activated by the peptide KiSS-1. J Biol Chem 276: 28969-28975, 2001.

35. Dhillo WS, Chaudhri OB, Patterson M, Thompson EL, Murphy KG, Badman MK, McGowan BM, Amber V, Patel S, Ghatei MA and Bloom SR: Kisspeptin-54 stimulates the hypothalamic-pituitary gonadal axis in human males. J Clin Endocrinol Metab 90: 6609-6615, 2005.

36. Dhillo WS, Chaudhri OB, Thompson EL, Murphy KG, Patterson M, Ramachandran R, Nijher GK, Amber V, Kokkinos A, Donaldson M, Ghatei MA and Bloom SR: Kisspeptin-54 stimulates gonadotropin release most potently during the preovulatory phase of the menstrual cycle in women. J Clin Endocrinol Metab 92: 3958-3966, 2007.

37. Ramachandran R, Patterson M, Murphy KG, Dhillo WS, Patel S, Kazarian A, Ghatei MA and Bloom SR: Preanalytical factors affecting RIA measurement of plasma kisspeptin. Clin Chem 54: 615-617, 2008.

38. Murphy KG, Abbott CR, Mahmoudi M, Hunter R, Gardiner JV, Rossi M, Stanley SA, Ghatei MA, Kuhar MJ and Bloom SR: Quantification and synthesis of cocaine- and amphetamineregulated transcript peptide (79-102)-like immunoreactivity and mRNA in rat tissues. J Endocrinol 166: 659-668, 2000.

39. Kong WM, Stanley S, Gardiner J, Abbott C, Murphy K, Seth A, Connoley I, Ghatei M, Stephens D and Bloom S: A role for arcuate cocaine and amphetamine-regulated transcript in hyperphagia, thermogenesis, and cold adaptation. FASEB J 17: 1688-1690, 2003

40. Wang D and Lawton C: Pelvic lymph node irradiation for prostate cancer: who, why, and when? Semin Radiat Oncol 18: 35-40, 2008.

41. Navarro VM, Castellano JM, Fernandez-Fernandez R, Tovar S, Roa J, Mayen A, Barreiro ML, Casanueva FF, Aguilar E, Dieguez C, Pinilla L and Tena-Sempere M: Effects of KiSS-1 peptide, the natural ligand of GPR54, on follicle-stimulating hormone secretion in the rat. Endocrinology 146: 1689-1697, 2005.

42. Navarro VM, Castellano JM, Fernandez-Fernandez R, Tovar S, Roa J, Mayen A, Nogueiras R, Vazquez MJ, Barreiro ML, Magni P, Aguilar E, Dieguez C, Pinilla L and Tena-Sempere M: Characterization of the potent luteinizing hormone-releasing activity of KiSS-1 peptide, the natural ligand of GPR54. Endocrinology 146: 156-163, 2005.

43. Gottsch ML, Cunningham MJ, Smith JT, Popa SM, Acohido BV, Crowley WF, Seminara S, Clifton DK and Steiner RA: A role for kisspeptins in the regulation of gonadotropin secretion in the mouse. Endocrinology 145: 4073-4077, 2004.

44. Castellano JM, Navarro VM, Fernandez-Fernandez R, Nogueiras R, Tovar S, Roa J, Vazquez MJ, Vigo E, Casanueva FF, Aguilar E, Pinilla L, Dieguez C and Tena-Sempere M: Changes in hypothalamic KiSS-1 system and restoration of pubertal activation of the reproductive axis by kisspeptin in undernutrition. Endocrinology 146: 3917-3925, 2005.

45. Waxman J: A new understanding of the hormonal regulation of endocrine dependent cancer. Br Med Bull 47: 197-208, 1991

46. Culig Z, Bartsch $G$ and Hobisch A: Antiandrogens in prostate cancer endocrine therapy. Curr Cancer Drug Targets 4: 455-461, 2004.

47. Morgan TM, Koreckij TD and Corey E: Targeted therapy for advanced prostate cancer: inhibition of the PI3K/Akt $/ \mathrm{mTOR}$ pathway. Curr Cancer Drug Targets 9: 237-249, 2009.

48. Harper AA, Hood AJ, Mushens J and Smy JR: Pancreotone, an inhibitor of pancreatic secretion in extracts of ileal and colonic mucosa. J Physiol 292: 455-467, 1979. 